\title{
Rethinking Missio Dei: a conversation with postmodern and African Theologies
}

\author{
A Meiring $^{1}$ \\ (University of Pretoria)
}

ABSTRACT

Rethinking Missio Dei: a conversation with Postmodern and African Theologies

When Missio Dei is examined from the perspective of Postmodern and African Theologies, new possibilities and metaphors emerge that can contribute to our understanding of God and Church's mission in the world. Missio Dei, it is shown, should also deal with panentheism, relationships, sacrifice and justice.

I would therefore dare to say that today I understand God better than I used to. This is due above all, of course, to the boundless grace of God, but my increasing understanding of African concepts of God was instrumental in the process. God used the richness of African religious experience to teach me more about his richness.

David Bosch (1973:73)

Missiology is, in the words of David Bosch (1978:240), the "theology of the church-crossing-frontiers": It studies the communication of the gospel to people outside Christianity, the establishment and building up of new churches, it addresses relevant social, political and economical issues, and it concerns itself with the theology of other religions and dialogue with people of these different religions and ideologies (theologia religionum). As a branch of Christian theology, and thus looking at the world from the perspective of commitment to the Christian faith, it nonetheless critically appraises every manifestation of the various aspects of the church's mission (Bosch 1991:9; Crafford 1996b:221; Kritzinger 1987:5; Schmidt 1988:20).

1 Dr Arno Meiring completed his PhD-thesis on Heart of darkness: A deconstruction of traditional Christian concepts of reconciliation by means of a religious studies perspective on the Christian and African religions under promotorship of Prof Piet Meiring, University of Pretoria. He is also Research Associate, Department of Missiology and Science of Religion, Faculty of Theology, University of Pretoria. 
I would like to thank my father, Prof Piet Meiring, for introducing me to the world of Missiology as a way of thinking and talking about God, for showing me how missiological questions challenge and enrich my own spirituality and for guiding and encouraging my studies in this discipline.

\section{MISSIO DEI AND MISSIO ECCLESIAE}

Missio Dei is one of the basic principles in Missiology and a foundation for mission since the beginning of the $20^{\text {th }}$ century. It refers to the insight that God is the primary actor when it comes to mission. Accordingly, mission is understood from a Trinitarian base: "just as the Father sent the Son into the world, and as the Father and Son together sent the Holy Spirit, so Father, Son and Holy Spirit send the Church into the world" (Meiring 1994:40-41).

As a result, the concept of Missio Dei asserts what we believe about God, about the role of the Church, and about the undertaking of mission:

We confess God to be a missionary God, a sending God, according to Bosch a “... fountain of sending love” (1991:390). The Second Vatican Council decreed that mission is "nothing else, nothing less, than the manifestation of God's plan, its epiphany and realisation in the world and in history" (Ad Gentium 2, 9). Thus, God is believed to be a sending (and sent) God by nature and by plan who takes the initiative in dealing with the world.

The Church, as missio ecclesiae, is sent to represent God and God's mission "in and over against the world, pointing to God ...in its mission, the church witnesses to the fullness of the promise of God's reign and participates in the ongoing struggle between that reign and the powers of darkness and evil (Bosch 1991:391).

Missiologists maintain that the Missio Dei, God's activity, embraces both the church and the world. Missio Dei is not limited by or dependent on the Church, but the Church's role is that of a coworker in mission that mostly discovers what God has already done (Bosch 1991:390; Meiring 1994:41). D T Niles once observed (in Bosch 1988:137): "I go expecting to meet the God who has preceded my coming and who has been preparing that person within the context of his or her own culture and conviction”. 
Missio Dei, then, articulates God's love for the world and God's initiative in saving it, which precedes and surpasses the Church.

\section{LIMITATIONS OF MISSIO DEI AND POSTMODERN THEOLOGY}

While the idea of Missio Dei vividly portrays God's love for humankind and the world, the concept may have its limitations and questions can be asked about its meaningfulness and depth (especially in popular use) from two very different, but not incompatible sides: Postmodern Theology ${ }^{2}$ and African Theology.

2 It should probably be asked whether the postmodern worldview is a usefull worldview and more importantly, whether theology can be done from a postmodern perspective. This will depend on a number of questions.

Firstly, the basis for this philosophy should be considered. It seems that postmodern philosophy is grounded in accepted science. Physicists show that the postmodern worldview appears to reflect the best science available. It is simply more responsible and honest to proceed from the best scientific basis possible. Of course the postmodern philosophy is not shared by all - especially not in South Africa where people have widely diverging worldviews. This should be kept in mind as a qualification on my use of postmodernism. Still, this qualification would be true for any chosen departure point in a heterogeneous world. Secondly, can a theology be postmodern? Theology deals with God, with the Ultimate, while postmodern theory rejects any notions of ultimate and abstract truths. A postmodern theology would certainly call into question many traditional Christian ideas, and challenge traditional beliefs. On the other hand, it could stimulate new and different ways of speaking and thinking about God. It is important to note that while postmodern theology does not accept abstract truths, it is not relativistic, as some theologians fear. Although truth is thought to be relative, this qualification does not mean that there are no truths, but it rather attributes truth to a statement in a given context or relation (Lowe 1999:21; Knitter 1985:219-220).

A number of Christian theologians have managed to come up with enriching postmodern theologies. Dirkie Smit (2002:119) admits that he is not yet quite convinced of the concept of "postmodern theology" but nevertheless espouses the postmodern perspectives in saying that truth is never absolute, but rather relative, historical and tentative. He even calls for anamnetic solidarity to listen to the voices of the previously unheard - which comes close to the approach of deconstruction (Smit 2002:102-105, 108). Jaap du Rand writes that his mindset changed from believing in eternal truths to coming to value contextualised metaphors as a way to express the inexpressible. He holds that theology is historical, contextual and metaphorical (Du Rand 2002:64, 69). I 
Postmodern hermeneutics makes use of a metaphorical understanding of reality, which means that when Christians describe God, their descriptions are understood to be no more than metaphors. While the metaphors highlight some aspect or experience of God, God is sometimes obscured or at other times reduced or limited by these metaphors. God remains much more than any metaphor can express. This metaphorical understanding of reality has obvious implications for theologians as it emphasises the human role in comprehending God's revelation: Humans judge or describe God in terms of their own experiences of God. So too, reality is no longer equated with the truth parallel to the relation between an object and its mirror image; God is only approximately known, and in a real sense, remains a mystery. "No metaphor can exhaust Him" (Burden 1990:192; Cupitt 1998:221; Herholdt 1998b:463-464).

It follows that we can (and should) question the relevance of certain metaphors for our day and age, and replace irrelevant or outdated metaphors. We can, for example, call God our "Friend" in the light of Feminist Theology, instead of "Father". Fortunately, we need not pretend that we understand God ontologically, but simply functionally, in God's relationships, acts and creation (Herholdt 1998b:464; Vosloo 2004:140).

Despite the obvious attraction of the Missio Dei-concept, it stands to question whether this idea and its associated suppositions, answers the questions posed by Postmodern and African Theologies. I would therefore like to suggest a rethinking ${ }^{3}$ of the concept of Missio Dei from these perspectives.

agree with Johan Dill (1996:228-229) that although some theologians see postmodernism as a threat, postmodern philosophy and deconstruction presents a promising challenge to theologians and stimulates constructive dialogue.

3 When suggesting a rethinking a Missio Dei, I am referring to the concept as it is used by present-day mostly conservative Reformed Evangelical theologians. When the concept of Missio Dei was coined after the Second World War, Hoedendijk and the Theologians of the Apostolate used this concept as a critical instrument to change the dominant understanding of mission. What I propose in this study was also suggested by them (Hoedendijk 1964:11-55). 


\subsection{Nature of God}

If Missio Dei celebrates God's coming into our world, then the theology seems to imply that - at least at some stage - God was not in the world. God only came to the world as a result of God's plan to save it. This concept sets God up against and in contrast to the world. Nowadays, Postmodern Theology seeks to move away from a dualist view of reality, to a view that reality is a multi-layered process where continuity exists between all things. Likewise, a postmodern spirituality does not contrast spirit and matter, but sees both as aspects of reality (Herholdt 1998a:227). Perhaps we should not contrast God and the world either?

Likewise, the supposed dramatic event of God, deciding to become involved and then sending Godself ${ }^{4}$ and then the Church into the world, does not correlate with a growing panentheistic realisation that God not only surpasses but also permeates the created world.

And the test for Christian theological models is exactly that: to provide meaning in terms of how the world is experienced in relation to the Christian belief in a benevolent God; and meaning demands a sense of coherence between our experience of God and the way we experience the world both physically and morally (Herholdt 1998a:224).

Of course, it entails, according to Herholdt (1998a:220), "that truth is no longer regarded as something with eternal, unchanging, authoritative and objective, absolute status. Truth is relative to a particular social context and personal presuppositions of the theologian”. The task of Postmodern Theology is not to discover or uphold an eternal, supernatural truth, but rather to provide a personal account of faith in order to increase meaning (Miller 1989:12; Herholdt 1998a:228).

The question is whether Missio Dei makes room for a Postmodern spirituality and view of God that does not set God against creation, but also experiences something of God in the world? This was what the Theologians of the Apostolate initially had in mind when stating that God's first involvement was creation, and

4 I use the word "Godself" instead of "Himself" as the masculine can obscure other alternatives. 
thus emphasised God's presence and involvement in the world as opposed to God's distance.

\subsection{Sin and salvation}

Missio Dei seems to indicate that the world is broken and needs to be restored through God's intervention. While this motif represents orthodox theology, a growing number of theologians have difficulty accepting "a Fall” that once and for all doomed the entire human race and creation.

James Miller makes the case:

If we are to speak in an illuminating way about evil in the universe, or, more particularly, about pervasive evil in human experience, then we need new stories which account for the reality of our experience of sin, stories which do not assume that the contemporary experience of evil is in some way a mechanical consequence of the act of a prehistoric ancestor.

(Miller 1989:17)

Hans Küng also believes that the idea of an original paradisiacunspoilt world, of a primal sin of the first human pair, and above all the Augustinian theory of an inherited sin - is flawed: "The first pages of the Bible cannot and are not meant to explain how historically and scientifically - the world, man and woman, sin came to be" (1974:422-423). Consequently, postmodern theologians reconsider the effect of sin on the world. The classical notion that the Fall is the cause of suffering and death is replaced by a view that suffering and death are natural phenomena. The tragedy of sin is not that it caused death per se, but that it qualifies death as a moral dilemma (Herholdt 1998a:227).

While Missio Dei does not spell out the exact manner in which the (sent) Son achieves salvation, He is usually understood (in line with Anselm's thinking) as a substitutuary sacrifice sent to propitiate God's wrath or sense of justice.

William Barclay (1961:122-123) disagrees:

If we think in terms of sacrifice or in terms of substitution, it almost necessarily means that something that Jesus did changed the attitude of God to men, that before the action of Jesus God could only punish and condemn men and that after the action of Jesus God was able and willing to forgive them ... [There] can be no 
doubt that this is a view which finds no support in Scripture. Nowhere does the New Testament speak of God being reconciled to men; always it speaks of men being reconciled to God ... [It] was never the attitude of God to man which had to be changed; it was the attitude of man to God.

The substitution model also undermines Christ's position. In the Reformed world, this view was often used within an infralapsarian framework, which explained that salvation was not intended at the creation, but became necessary because of sin. Thus, Christ was only needed to solve the problem of human sin and guilt. It relegates Christ to being an emergency measure and somewhat less than an ideal self-revelation of God (Van de Beek 2004:36).

Hayes (1998:175) points out that Anselm's model changed the way Christians understood sin. "Instead of seeing sin primarily as something that God rescues us from, Western European Theology came to see sin primarily as something God punished us for". This was aided by the idea of the privatisation of religion, where religion was seen as something concerned only with one's relationship with God, and divorced from the rest of life.

John Dominic Crossan calls this theory: “... the most unfortunate successful idea in the history of Christian thought ..." because it gave the church worldly power by creating a sense of debt and a lever for social control. He continues: "If I can persuade you that there is a punishing God and that you deserve to be punished but I have some sort of way out for you, then that's a very attractive theology" (in Van Biema 2004:42).

It also delivers a disempowering message: "Countless women have told me that their priest or minister had advised them, as 'good Christian women' to accept beatings by their husbands as 'Christ accepted the cross'. An overemphasis on the suffering of Jesus to the exclusion of his teaching has tended to be used to support violence" (Susan Thistlethwaite in Van Biema 2004:42).

Hans Küng explains that Anselm's theory does not so much reflect New Testament teaching as the theology of the Middle Ages and the juridical-rational idea or order then prevailing. His intention was admirable: He made the old tradition understandable to a new generation with a new background of experience, using forms of 
thought and language common to believers and unbelievers of his day. Küng (1974:424) asks:

... if this was permitted to medieval theology, can we forbid to modern theology its own fresh approach? We can no more commit ourselves now than in New Testament or patristic times to a particular conceptual framework - whether juridical, cultic, metaphysical, or even scientific, technical, physiological, sociological for the interpretation of the highly complex event of the redemption.

The theory, therefore, of the death on the cross as an expiatory sacrifice, understandable for Jewish Christians at that time, is only one and not the most important model for the interpretation of Jesus' death. Since cultic sacrifices are no longer offered in the modern environment, the concept of sacrifice is not related to any experience and has thus become largely misleading and unintelligible. The permanent, definitive and irrevocable significance and effect of Jesus' death must be freed from the restrictions of the older terminology and interpreted in modern man's horizon of experience, in order to have an impact in the modern world (Küng 1974:426).

The very negative evaluation of the human condition and the medieval theology that goes with it, may be incomprehensible to many people today. If the meaning of Missio Dei is diminished to underscore only this view, it is surely lacking. On the other hand, for many missiologists (as I have shown) the concept of Missio Dei emphasises the opposite; it shows God's overwhelming love and positive involvement in (and assessment of) the world.

\subsection{Missio Ecclesiae}

Missio Dei rightly relativises the role of the Church in saving the world: the Church is merely one actor in God's salvation plan, and does not exhaust God's concern for the world. A "sent" Church emphasises obedience and a witnessing character, rather than a triumphant bearer of an ecclesiasticised salvation (Bosch 1991:217218).

Often, though, the way in which some missiologists apply the role of the Church needs to be questioned. The confidence, certainty and passion of some sent churches more resemble that of a power broker than a meek servant. Churches take their stand against all 
they perceive to be the world and eagerly draw battle lines against what they determine to be dark and evil powers. The danger exists that missional churches only focus on being big and successful, heavily involved in the building up of a particular congregation, and announcing their missionary nature as if it made them God's divine agents, instead of God's servants for the benefit of the world. They may mean successful when they say missional, and have in mind huge congregations with excellent facilities (Burger 1999:298).

And what role does the Church, in turn, present "the world"? Can the Church's objective proclamation of salvation, without participation of those who are to be saved, really save them? Bauman (1998:69-71) argues that in a postmodern era, people are not impressed or affected in a personal way by the accounts of revelation and ecstasy of saints, hermits and monks, but, as sensation gatherers, want to experience this for themselves. Same goes for salvation.

Postmodernism has challenged determinism to the extent that randomness and unpredictability have gained a positive meaning as mechanisms necessary for creativity and novelty. It seems that people are beginning to believe that we live on the edge of chaos, and that the intrinsic dialectic of order and chaos is offering new insights into the meaning of freedom. Thus, the will of God is not a predetermined decision that Christians need to discover in a passive mode of obedience, but instead, Christians are afforded the right to some human input that co-determines the 'plan' for their lives. So too, humans need not plug into a blueprint that renders their own efforts and creative potential sterile, but are co-creators. It follows that postmodern theologians discover truths about God by participating in a relationship with God - they discover and create truth at the same time (Cupitt 1998:220; Dill \& Kotzé 1997:9; Herholdt 1998a:217, 224; Milbank 1997:270; Niemandt 2007:553).

... the believer is not called upon to master abstract truth, rather he or she is challenged to make sense of the world by participating in the creation of a new world in terms of which the self can be defined. Faith is therefore my own experience and theology the story or account of my life.

(Herholdt 1998a:225)

A missional Church, it seems, would do well if it addresses the world with more humility and vulnerability, and allows its hearers to 
participate in finding and understanding God on their own terms, rather than to simply proclaim what it holds to be the truth.

\subsection{Eschatology}

The concept of Missio Dei comprises a rich eschatology that rightly emphasises the continuous comings of God to the world through the Son, Holy Spirit and Church. Unfortunately, the future coming of God often overshadows God's initial sending in the minds and hearts of many Christians. This undermines the more creative tension between the already and the not yet, and leads to a preoccupation with "what will be" instead of "what is at hand" (Bosch 1989:142; 1991:508-509).

Zygmunt Bauman (1998:59) argues that Christianity encourages people to focus on their posthumous fate in order to produce consumers for its product. Michel Foucault (in Bauman 1998:59) wrote that:

... all those Christian techniques of examination, confession, guidance, obedience, have one aim: to get individuals to work at their own 'mortification' in this world. Mortification is not death, of course, but it is a renunciation of this world and of oneself: a kind of everyday death. A death which is supposed to provide life in another world.

In contrast, Bauman (1998:63-69) believes that our society has undergone an "anti-eschatological revolution", whereby human beings are more concerned and insecure about their human identity, existence and everyday problems, and less interested in their posthumous fate.

Unlike the ontological insecurity, identity-focussed uncertainty needs neither the carrot of heaven nor the stick of hell to cause insomnia. It is all around, salient and tangible, all-too-protruding in rapidly ageing and abruptly devalued skills, in human bonds entered until further notice, in jobs which can be taken away without any notice, and in the ever new allures of the consumer feast, each promising untried kinds of happiness while wiping away the shine of the tried ones.

(Bauman 1998:68) 
Christianity should not try to change the insecurities and insufficiencies of human beings, but rather address their real needs. Postmodern humans' problems are this-worldly: Christianity should give people this-worldly answers.

Correspondingly, a realised eschatology demands justice here and now. Stephanie Mitchem (2002:260) pleads for a kind of “... reconciliation (that) challenges all oppressive, dehumanizing systems, not merely restoring the former order, but rebalancing the old so that a new heaven and earth can begin".

Establishing the reign of God on earth, fighting for justice and addressing people's real, this-worldly problems and needs are as much part of the missional agenda as anything else. A Missio Dei that discounts this world is a contradiction in term.

\section{DECONSTRUCTION}

One manner in which to rethink the concept of Missio Dei is through the process of deconstruction. Jacques Derrida formulated the approach of deconstruction for literary study. According to him, certain traditions or discourses dominate Western thought to the extent that it impedes other possible ideas and alternatives. Deconstruction seeks to undo (and not destroy) these dominant traditions in order to bring the alternatives to the fore (Lechte 1994:107-109).

Deconstructionism holds that we know reality only in language, but that this is an "unreal reality" like a game that is played, not against the background of a fixed, stable reality, but rather a field of freeplay and infinite substitutions. It differs from structuralism in the sense that it does not view the text as an independent unit that influences the subject, but views both the subject and the text as part of an intertextual world (Heelas 1998:8; Herholdt 1998b:453-454).

Kotzé \& Kotzé (1997:8) explains that one of Derrida’s central methodological devices to accomplish this feat hinges on the notion of placing a term under erasure (sous rature). A word is literally first written and then erased, keeping both the erased word and the word itself simultaneously. The erasing is a strategy to accentuate that the term is both needed and not needed at the same time. They explain:

This strategy of sous rature is used to employ the familiar and commonly known, to deconstruct the 
familiar and known. The word under erasure is used to reveal its status as useful, necessary and at the same time wrong and not useful. $\mathrm{X}$ is at the same time $\mathrm{X}$ and its opposite, not-X. Words being used are therefore necessary in order to understand, while they are at the same time inaccurate. Within the meaning of any possible text there is also its opposite text.

In short, words are necessary in order to defer meaning; at the same time these words are inaccurate as they obstruct the difference between the word and the intended meaning. It follows that if words can obstruct true meaning, so too can our discourses. Deconstruction thus demands that we take apart the interpretive assumptions of a system of meaning in order to reveal the assumption on which the model is based. As these are revealed, you open up space for alternative understanding (Wolfreys 1998:58-59; Lechte 1994:107; Kotzé \& Kotzé 1997:8).

Deconstruction can be applied more universally. In analysing gaps, silences and ambiguities, it also exposes ethno- and androcentrism, as well as prejudices of class, race and religion. Deconstruction aims to expose this aspect of reality, deconstructing dominating ideas and highlighting other options. It provides “... a corrective moment, a safeguard against dogmatism, a displacement, to keep it in process, to continuously demystify the realities we create” (Kotzé \& Kotzé 1997:7-8).

\section{AFRICAN THEOLOGY AND MISSION}

In this section I will seek to deconstruct the concept and suppositions surrounding Missio Dei by exploring a number of insights from African Theology. These may offer alternative ideas on mission, God, the world, the Church and eschatology that can supplement or better the accepted Western notions.

\subsection{An African Theological view of God}

African Religion teaches that God exists. This God, who created all things, is eternal, all knowing, ubiquitous, and beyond description. Credo Mutwa (1998:561) beautifully explains:

The Most Ultimate God, who is the God of the Gods of the Gods, is Everything in Everything. Each tree, each blade of grass and each stone that you see out there, and each one of the things that live, be they men or beasts, are 
all parts of God, just as each one of the hairs on your head and each flea in your hair and each drop of blood is part of you. The sun is part of God; the moon is part of God and each one of the stars is but an infinitesimal part of Him who Is, and yet is not, Him who Was, and yet was not, and Him who Will Be, and yet shall never be; because there never was a time when God was not and there never is a time when God can never be.

God is believed to be not only transcendent, but also immanent. While many scholars label Africa's idea of God as an uninvolved deus otiosus or a concealed deus absconditus (as many myths suggest), Africans also experience God as immanent: “... He is so 'far' (transcendent) that men cannot reach Him; yet, He is so 'near' (immanent) that He comes close to men" (Mbiti 1969:32). While God transcends all concepts of time and no one is beyond Him, He is so immanent that humans can make contact with Him through prayers, sacrifices and invocations. He is also near in the sense that He fills all creation, but then more in a panentheistic fashion, rather than a pantheistic manner (Crafford 1993:167; Crafford 1996:13; Eliade 1958:47-49; Mbiti 1969:32; Mutwa 1998:559).

Prominent African theologians share this view of God. They assert that the message of Christianity was not entirely new for Africa, and that African culture already resembled the worldviews of the Bible. An Ashanti proverb explains that: "No one show(s) a child the Supreme Being”, meaning that everybody knows of God's existence almost by instinct', even children know Him (Bediako 1995:97; Mbiti 1969:29; Mbiti 1998:140-142).

Mbiti (1998:142) himself believes that:

The Bible is very much an African book, in which African Christians and theologians see themselves and their people reflected and in which they find a personal place of dignity and acceptance before God.

At the first conference of African theologians in Ibadan, Nigeria, in 1966, the African theologians formulated this belief as follows:

We believe that the God and Father of our Lord Jesus Christ, Creator of heaven and earth, Lord of history, has been dealing with mankind at all times and in all parts of the world. It is with this conviction that we study the rich 
heritage of our African peoples, and we have evidence that they know of Him and worship Him. We recognise the radical quality of God's self-revelation in Jesus Christ; and yet it is because of this revelation that we can discern what is truly of God in our pre-Christian heritage: this knowledge of God is not totally discontinuous with our people's previous traditional knowledge of Him.

(in Mbiti 1998:151)

Thus African Theology agrees with Mutwa's (African Traditional Religion's) understanding of a panentheistic God. God is part of the world (Adeyemo 1998:374; Crafford 1993:176; Du Toit 1998:392; Kobia 2003:95; Thorpe 1991:123).

Perhaps this may serve as a corrective on the dualistic view that detaches God from the world, as Missio Dei surely was not meant to imply.

\subsection{African Theology on Sin and Salvation}

African Theologians do not understand sin in terms of a "Fall", but see sin rather as a breach of or a threat to the community. Kgatla (1995:126) explains that "sin is inherently the destruction of the group's solidarity, so that a person sins, not against God, but against others".

This different view of sin proceeds from the logic that God is the creator of everything including society. Society, according to African belief systems, is a moral entity since the Creator provided a moral code which directs individual behaviour patterns. However, this moral code can be violated, and any infraction of it is regarded as sin, which earns the displeasure of God. Such sinful acts include immoral behaviour, breaking covenant, ritual mistakes, breaking of taboos, committing an abominable act, offence against God or man and pollution. Thus, while many Christians often conceptualise the source of evil as the devil or sin, African Religion (and Theology) tend to locate the source of evil firmly in the human world, in the disruptive ambitions and jealousies of people. Such people are witches or sorcerers. Sin creates imbalance in the relationship between God and man or between man and man. Such imbalance is usually attended by catastrophe not only to the offender but also to the whole community (Maimela 1985:65; Mbiti 2005:1; Ndwandwe 2000:213; Thorpe 1991:114; Ubruhe 1996:18). 
African religion is thus a moral or ethical religion that dictates a certain way of living and relating, the purpose of this ethical consideration being life in its fullness. Africans quickly draw ethical conclusions about thoughts, words, and actions of human beings, or even of "natural" cosmological events, by asking questions such as: Does a particular act or happening promote life? If so, it is good, just, ethical, desirable, and divine. Or, does it diminish life in any way? Then it is wrong, bad, unethical, unjust, or detestable (Magesa 1997:77,285; Ndwandwe 2000:213).

What traditional Christianity abstractly calls "sin" or "evil” is better expressed in African religion by the concept of "wrongdoing", "badness" or "destruction of life". Although the more abstract notions of sin exist within the African religious consciousness, African religion's moral perspective is concrete and pragmatic. The African concept of sin is therefore conditional. Sin does not exist in an absolute sense but always within the community and creation, which is determined by the context, the actors, time and place, etcetera (Nolan 1988:192; Theron 1996:118-119; Magesa 1997:161; Ndwandwe 2000:213).

Kgatla believes that the African view of sin is similar to that of ancient Israel:

In ancient Israel sin in life could not be separated from the notion of the covenant relationship. This means that the relationship between Yahweh, and the individual and the rest of the community should never be disturbed by actions which were forbidden by law. Any behaviour which threatened the natural carrying on of life in the community was considered as a sinful deed.

(Kgatla 1995:126)

African philosophy thus considers the presence of community itself as reconciliation and salvation. The community is believed to heal the human sense of estrangement from God. Thus, all efforts to create, recreate or restore the community boils down to reconciliation with both the members of society and with God. African thought rightly sees that the relationship with humans and the relationship with God are inseparable.

Archbishop Desmond Tutu explains that the story of Adam and Eve relates a fundamental truth about humans - that we are made to 
live in a delicate network of interdependence with one another, with God and with the rest of creation. According to Tutu, a solitary human being is a contradiction in terms: "A totally self-sufficient human being is ultimately subhuman. We are made for complementarity. ... We need each other to become fully human" (1996:xiv). Likewise, a deep connection with the community inspires personal growth:

A person with ubuntu is open and available to others, affirming of others, does not feel threatened that others are able and good; for he or she has a proper selfassurance that comes from knowing that he or she belongs in a greater whole and is diminished when others are humiliated or diminished, when others are tortured or oppressed, or treated as if they were less than who they are.

(Tutu 1999:35)

The all-importance of the community also implies that even an offender's wellbeing is an important part of reconciliation. It is only once the offender's dignity is restored, that reconciliation can take place (Ndwandwe 2000:214).

Typically, African Theology sees salvation taking place when communities open up to welcome new or estranged members. Archbishop Njongonkulu Ndungane (2003:103) explains:

When we refuse to allow difference in our communities and when we ostracize those who are the 'other', we deny ourselves and others the opportunity to be fully human. African culture invites us to embrace the 'other' and to discover a fuller and richer humanity. This understanding of our humanity echoes, of course, the profound insights offered by the Christian doctrine of the Trinity, which celebrates a loving communion of free, self determining, creative persons.

Ndungane adds that we now have the opportunity to challenge the exclusivism which prefers men above women, whites above blacks, rich above poor, and straight above gay, because our Triune God invites us to demonstrate that in our very differences, we can embrace one another, celebrating otherness, and discovering our deep, Godly unity in those differences (2003:107). 
Desmond Tutu (1999:213-214) finds this in the New Testament:

There is a movement, not easily discernable, at the heart of things to reverse the awful centrifugal force of alienation, brokenness, division, hostility and disharmony. God has set in motion a centripetal process, a moving towards the Centre, towards unity, harmony, goodness, peace and justice; one that removes barriers. Jesus says, "And when I am lifted up from the earth I shall draw everyone to myself," as He hangs from His cross with out-flung arms, thrown out to clasp all, everyone and everything, in a cosmic embrace, so that all, everyone, everything, belongs. None is an outsider, all are insiders, all belong. There are no aliens, all belong to the one family, God's family, the human family. There are no longer Jew or Greek, male or female, slave or free - instead of separation and division, all distinctions make for a rich diversity to be celebrated for the sake of the unity that underlies them. We are different so that we can know our need of one another, for no-one is ultimately self-sufficient.

Put differently, in African Theology both sin and salvation hinges on relationships. Relationships hold the key to both divining God's will and expressing that will. God wants relationships; the purpose of creation is relationships; the goal of one's life is relationships. This is true community, humanity, ubuntu (Magesa 1997:285).

African theologians would therefore probably interpret the idea of Missio Dei as that God came to establish and heal relationships, inviting people into God's community, rather than simply fulfilling an imagined juridical requirement. The African emphasis also challenges the Western Church's often quite individualistic understanding of salvation.

\subsection{An African view of the Church}

While some Western missional churches' very confident proclamation of themselves and their success often contrasts its intended call to obedience and humility, African churches do not so much proclaim as embody its view of salvation, and offer opportunities for its members to relive and participate in the 
restoration of the community with God and humans (Daneel 1987:273; Crafford et al 1984:48).

Daneel (1987:273) describes how congregants in an African Initiated Church participate:

Sermons are interspersed with prophesy, confession, testimonies to joy or grief, laying on of hands, faith healing and exorcism. Thus the need of the individual is shared and carried by the church. During exorcism the beleaguered soul is tied with sacred cords, and this symbolic act is accompanied by rhythmic song. The demon is then addressed, cursed and expelled by means of numerous symbolic acts. It is all deadly earnest, but if the exorcism should suddenly sound funny, people will laugh and delight at the rebuking of the unwelcome spirit - without in any way marring the seriousness of the situation.

In addition to its participatory nature, African Theology envisages a different style of Church. Both Abe (1996:7) and Ubruhe (1996:20) present African folk tales, like that of Eleguru, as an important resource for an African Theological understanding of discipleship and ecclesiology. According to the legend, Eleguru was a divinerpriest who later became the "Saviour" of the Ijebu-Ode people. He voluntarily offered himself as a propitiatory sacrificial victim of scapegoatism to redeem the Ijebu-Ode people from the constant disastrous deluge of the lagoon which swept away numerous men and women of the land and their properties (Abe 1996:7).

The tradition narrates how the Ijebu-Ode people were constantly menaced by the Osa (lagoon) that overflowed its banks and caused incalculable destruction of lives and property. The deluge became a source of anxiety among the people. In their attempt to stem the threat of the disastrous deluge, the people consulted the Ifa Oracle. The diviner-priest divined that a human victim was needed as sacrifice. To the utter surprise of everybody, Eleguru, who was the diviner on the eventful day, presented himself as the priest as well as the victim to be offered. On the appointed day, Eleguru came prepared to perform the sacrifice and to die. He spread a mat on the lagoon, placed all his divination paraphernalia on the mat and sat on it. It gradually moved away into the lagoon as he uttered some incantations. Eleguru paid the supreme sacrifice by sinking into the 
lagoon, and his death marked the termination of the threat from the lagoon (Ubruhe 1996:20).

René Girard argues that the Bible also counters scapegoatism ${ }^{5}$, which constantly threatens community, through such voluntary selfsacrifices which, in effect, exposes and defeats the pattern of scapegoatism. Jesus, for example, becomes the "Lamb of God" and breaks the evil power of scapegoatism (Girard 1982:221). According to Girard, Jesus gave himself up as a voluntary self-sacrifice, not to appease God's wrath, but rather to enlighten people: to reveal the evil pattern of scapegoatism and in doing so to recognise the real causes for their suffering, and to challenge them to take responsibility for their own lives and welfare (Girard 1982:125-140).

The emphasis of African ecclesiology of the embodiment and re-enactment of salvation, and that this happens particularly when the Church becomes willing to sacrifice itself, its success and prestige, as a way in which to establish a more just and fair society offers the kind of credibility for a sent Church that parallel that of Godself.

\subsection{African eschatology}

John Mbiti explains that traditionally, Africans do not have a futuristic eschatology. They look back to a golden era when all lived in harmony, and have little awareness or interest in the future. In Mbiti's (1969:16-17) well-known explanation of the African concept

$5 \quad$ Girard (1982:7-19) explored the phenomenon of scapegoats and he made fascinating findings. He says that when a community is faced with a universal threat, they usually attempt to counter it by identifying an innocent scapegoat (or a few scapegoats). The scapegoat then bears their anger while they come to terms with the problem. He illustrates how this was done to the Jews in Guillaume de Machant's poem, "Judgement du Roy de Navarre", when pestilence threatened France in 1349 and the people reacted by accusing the Jews of poisoning their water and proceeded to massacre them.

Girard maintains that the pattern of scapegoats which surfaces in all cultures and communities underlies most of our history and is even reflected in our myths (for example in the myth of Oedipus). He also finds this pattern in the Bible, but with this difference that the Biblical accounts reject and protest against the scapegoatism. Whenever someone is made into a scapegoat in the Bible, his or her innocence is pointed out. This is true of Psalm 35, Isaiah 53, and even more so of Jesus. Jesus is said to be crucified without cause (cf Jn 15:25, Lk 12:34, Jn 11) (Girard 1982:125-140). 
of time, he makes the point that for Africans the future extends to a period of about six months - two years at the most. Events outside this range lie beyond what constitutes actual time. "At most we can say that this short future is only an extension of the present" (1969:17).

Christianity and the modern changes that swept through Africa during the last century brought an awareness of a brighter future for many Africans with sometimes dangerous consequences. Mbiti (1969:221) explains:

Their hopes are stirred up and set on the future. They work for progress, they wait for an immediate realisation of their hopes, and they create new myths of the future. It is here that we find the key to understanding Africa's political, economic and ecclesiastical instability.

As a result, many African Christians have a futuristic hope of an immediate arrival of paradise. They cannot, according to Mbiti (1969:235) "conceive the possibility that the end of the world is an ultra-historical myth which cannot be fitted into the immediate conceptualisation of individual men and women. They are bitterly disappointed when their Christian relatives start to die”.

Consequently, African eschatology is decidedly this-worldly, and looks toward the immediate realisation in a this-worldly community (Bediako 1995:101; Du Toit 1998:393).

African Theology's this-worldly focus is one of the reasons that it emphasises justice and freedom. African theologians, along with other liberation theologians from the Third World, strongly emphasise the idea that salvation (concretely) entails solidarity with the oppressed or suffering: "... Jesus is the friend who stands in solidarity with the marginalised...” (Oduyoye 1998:362).

Thus, Canaan Banana (1976:156-157) prays:

OUR FATHER WHO ART IN THE GHETTO, DEGRADED IS YOUR NAME, THY SERVITUDE ABOUNDS, THY WILL IS MOCKED, AS PIE IN THE SKY.

TEACH US TO DEMAND, OUR SHARE OF GOLD, 
FORGIVE US OUR DOCILITY,

AS WE DEMAND OUR SHARE OF JUSTICE.

\section{LEAD US NOT INTO COMPLICITY, DELIVER US FROM OUR FEARS.}

\section{FOR OURS IS THY SOVEREIGNTY, THE POWER AND THE LIBERATION, FOR EVER AND EVER, AMEN.}

The acid test for a thorough understanding of the Missio Dei, could be whether we are willing to take seriously Canaan Banana in his prayer (or at least understand where he is coming from). Eschatology is as much about liberation as about heaven.

\section{CONSEQUENCES FOR MISSIO DEI}

The questions raised by both Postmodern and African theologians demand a rethinking of Missio Dei. The concept may be enriched by adding (or remembering) at least four dimensions.

\subsection{A panentheistic God}

The idea that God can be considered panentheistic ${ }^{6}$ is quite controversial and presently one of the hottest debates in the Dutch Reformed Church. If it is universally accepted, it can be a corrective to the erroneous supposition the God was at any stage, not completely (if not exhaustively), in the world.

This understanding may be based on Paul's contention that God revealed Godself not only through Christ, but also in nature. It is interesting that Calvin, in the introduction to the Institutes, said something in this vein, namely, that theology comprises the study of God, man and nature, but that it makes no difference in principle whether we begin with God or man or nature, since dealing with or reflecting on the one automatically entails and leads to dealing with and reflecting on the other two. One of the most profound implications of this Calvinist position is that none of the three subjects of theology - God, man and nature - is (strictly)

6 I use the word "panentheism" to refer to the ubiquitous nature of God: God can be seen in the world while at the same time exceeding it. Although there are other, less "innocent" definitions of panentheism, I argue for a definition that could be accepted and accommodated by most. 
objectifiable (Calvijn 1931:1-4). While Missio Dei is believed to reject the dualism between the profane and the spiritual on a human level (Niemandt 2007:553), the same can be asked of the dualism often stated between God and God's world.

\subsection{Salvation and relation}

If salvation is all about relationships, instead of only having a price paid for Adam's sin, and if it also entails opening up the community and restoring it, as African Theology maintains, then the concept of Missio Dei can surely (and should more explicitly) signify that: God and the Church are sent to the world in order to establish a new community. Still, the concept of "incarnation" or the simple acceptance of all will convey the African view even better.

John Milbank (1997:273-274, and also Ruether 2002:xv) asserts that the idea of salvation by means of a community is thoroughly Christian, and that Christ overcomes evil in community with his followers, providing a memory of perfect community and a new language of community. It is called the Logos, the lost harmonic pattern of genuine human life, which can now be reappropriated. Can Missio Dei also put across these perspectives?

\subsection{Kenosis}

If we remember that Jesus Christ, the Son, died on a cross, and that He called his disciples to bear their own crosses, the mission is hardly meant to be a triumphant, successful kind of mission. Philippians calls it kenosis, a self-emptying, humiliating process. Perhaps the Church should rather take on this adjective to describe and understand itself: Not only as a "missional" Church but also as a "kenotic" Church?

This self-sacrifice is the heart of the Christian message; it stands against evil and violence; the expulsion and sacrificing of others (Milbank 1997:271). Sacrifice also invites participation. Bosch wrote (1982:26): "the ministry of reconciliation ... [means] that I should be prepared to do more than [the other person] did, to go the 'second mile'. If $I$ begin to change, it becomes possible for him to change too".

\subsection{Solidarity}

Solidarity refuses to neglect this world and its problems and denies any spiritual retreat. It focuses our attention on the real issues of the 
day. This, according to Daniël Veldsman, was the intention of salvation:

... this idea was also espoused by Moltmann who said that through the cross, Jesus identified himself with the present reality of the world in all its negativity. The cross represents solidarity.

(Veldsman 1998:61)

Correspondingly, Dirkie Smit (2002:108) and Wolgang Huber (1993:590) call attention to the importance of anamnetic solidarity: "This solidarity has to be oriented toward the destiny of the weaker, to the suffering of the victims. A preferential option for the victims instead of for the heroes is the appropriate way to deal with history" (Huber 1993:590). It is important that Missio Dei pays real attention to justice, liberation and solidarity with the marginalised.

\section{CONCLUSION}

The San people tell a curious story:

The Mantis [the divine trickster !Kaggen] made an Eland from his son-in-law /Kwammanga's shoe. /Kwammanga missed his shoe but neither he nor his wife had any idea what happened to it. Meanwhile Mantis collected honey and fed it to the Eland which he had made as it came out of the reeds to eat. Mantis's family wondered why he brought so little honey home for them, and finally they sent Ichneumon [his grandson] to hide beneath a kaross and see what happened to the honey. Watching, he saw the Eland come from the reeds and drink the water into which Mantis had put the honey. Mantis even smoothed the honey water onto the Eland's skin. Then Ichneumon jumped out from underneath the kaross. Quickly Mantis drove the Eland away, but Ichneumon confronted him with what he has seen. As they argued, Mantis denied the existence of the Eland. On his return, Ichneumon reported what he had seen.

Secretly Porcupine's family plotted together and went to the pool where Ichneumon had seen Mantis feed and stroke the Eland. /Kwammanga then put honey into the water and called the Eland by name, whereupon it came out of the reeds to drink. As it drank /Kwammanga shot it. It ran back into the reeds, where it lay down to die. 
Meanwhile Mantis was looking for honey to feed his beloved Eland, but he could not find any. Feeling a strange sense of foreboding, he went to the water to call the Eland, but it did not come. He wept as he sought his Eland, following its spoor and then the drops of its blood. At last he saw it lying dead in the reeds. Weeping and angry, he returned home. In the meantime /Kwammanga had commissioned meerkats to cut up the dead Eland. Mantis ran back to where Eland lay. When he saw the meerkats busy slaughtering his animal, he tried to stop them by shooting arrows, which however, missed their mark. Next he attacked them with a knobkerrie, but all to no avail. Finally, a meerkat snatched the knobkerrie from Mantis's hand and, after beating him, made him collect wood for a fire. While he was thus busy, Mantis saw Eland's gall bladder hanging on a tree. He pricked it open so that everything and everyone was covered in darkness. When he realised what he had done, he quickly removed his own shoe, which had red dust still clinging to it, and threw it into the sky where it became the moon.

(Thorpe 1991:18-19)

Sir Laurens van der Post (in Thorpe 1991:20), interpreting this myth, explained that the Mantis represents a loving, caring creator. And Mantis's sorrow over the loss of Eland, is the loss for the separation that exists between creator and creature. Thorpe adds that the creation of the moon may suggest the "inner spirit of the human soul which rises above the felt bitterness of an experienced moment to shine again, lighting the way no longer for oneself alone, but also for others".

It is interesting that despite all the strange dealings in this myth, in the end the Mantis, the God-like character, simply restores and heals the broken, bitter world. Even though this myth is not Christian at all (but at least African), it makes the most important point: God takes the initiative; God's love makes the difference. As long as Missio Dei reminds us of what God does, as opposed to what we (can) do, it serves its purpose. I believe that the metaphors that I put forward - panentheism, salvation through relationships, kenosis and solidarity - may do the same. 


\section{Consulted literature}

Abe, G 1996. Redemption, reconciliation, propitiation: Salvation terms in an African milieu. Journal for Theology in Southern Africa 95, 3-12.

Adeyemo, T 1998. Clash of Two Worldviews: African and Western. Orientation 87-90 (Signposts of God's Liberating Kingdom: Perspectives for the $21^{\text {st }}$ century - Volume 2), 369-386.

Banana, C 1976. The Lord's Prayer - In The Ghetto in Anderson, G H \& Stransky, T F (eds), Mission Trends No. 3: Third World Theologies, New York: Paulist Press \& Grand Rapids: Eerdmans, 156-157.

Barclay, W 1961. Crucified and Crowned. London: SCM Press.

Bauman, Z 1998. Postmodern Religion?, in Heelas, P (ed) Religion, Modernity and Postmodernity, Oxford: Blackwell Publishers, 55-78.

Bediako, K 1995. Christianity in Africa: The Renewal of a Non-Western Religion. Edinburgh: Edinburgh University Press.

Bosch, D J 1973. God through African Eyes in Becken, H J (ed) Relevant Theology for Africa, Durban: Lutheran Publishing House, 68-78.

-, 1978. Missiology, in Eybers I H, König, A \& Stoop, J A (eds) Introduction into Theology, Pretoria: NG Kerkboekhandel, 230-243.

-, 1982. The Church as Alternative Community. Potchefstroom: IRS.

-, 1988. The Church in Dialogue: From Self-Delusion to Vulnerability. Missiology 16:2 (April 1988), 131-145.

-, 1991. Transforming Mission. Paradigm shifts in the theology of mission. New York: Orbis.

Burden, J J 1990. No-one is an Island: Proverbs, Context and the Bible. Missionalia 18:1 (April 1990), 181-194.

Burger, C 1999. Gemeentes in die Kragveld van die Gees. BUVTON: Stellenbosch.

Calvijn, J 1931. Institutie: Of Onderwijzing in den Christelijken Godsdienst. Delft: W D Meinema.

Crafford, D, Boshoff, C W H \& Daneel, M L 1984. Pluralisme as Religieuse Verskynsel: Die Onafhanklike Swart kerke en Bewegings en Groepsverhoudinge in Suid-Afrika. Pretoria: ISWEN.

Crafford, D 1993. The church in Africa and the struggle for an African identity. Skrif en Kerk 14(2), 163-175.

-, 1996a. African traditional religions, in Meiring, $\mathrm{P}$ (ed), A World of Religions: A South African Perspective, Pretoria: Kagiso, 1-26.

-, 1996b. The theology of religions, in Meiring, P (ed), A World of Religions: A South African Perspective, Pretoria: Kagiso, 220-244.

Cupitt, D 1998. Post-Christianity, in Heelas, P (ed) Religion, Modernity and Postmodernity,. Oxford: Blackwell Publishers, 218-232 
Daneel, I 1987. Quest for Belonging: Introduction to a study of African Independent Churches. Gweru: Mambo Press.

Dill, J 1996. 'n Basisteorie vir Pastorale Terapie in die Lig van Postmoderne Epistemologie. Ongepubliseerde verhandeling, Universiteit van die OranjeVrystaat.

Dill, J \& Kotzé, D J 1997. Verkenning van 'n Postmoderne Epistemologiese Konteks vir die Praktiese Teologie. Acta Theologica 1997(1), 1-26.

Durand, Jaap 2002. Hoe my gedagtewêreld verander het: van ewige waarhede tot gekontekstualiseerde metafore. Ned Geref Teologiese Tydskrif 43:1-2, 64-70.

Du Toit, C 1998. African Hermeneutics, in Maimela, S \& König, A (eds), Initiation into Theology: The Rich Variety of Theology and Hermeneutics, Pretoria: J L van Schaik, 373-398.

Eliade, M 1958. Patterns in Comparative Religion. New York: Sheed and Ward.

Girard, R 1982. De Zondebok. Kampen: Kok Agora.

Hayes, S 1998. African Initiated Church Theology, in Maimela, S \& König, A (eds), Initiation into Theology: The Rich Variety of Theology and Hermeneutics, Pretoria: J L van Schaik, 159-178.

Heelas, P 1998. Introduction: on differentiation and dedifferentiation, in Heelas, P (ed) Religion, Modernity and Postmodernity, Oxford: Blackwell Publishers, 1-18.

Herholdt, M D 1998a. Postmodern Theology, in Maimela, S \& König, A (eds), Initiation into Theology: The Rich Variety of Theology and Hermeneutics, Pretoria: J L van Schaik, 215-229.

-, 1998b. Postmodern Hermeneutics, in Maimela, S \& König, A (eds), Initiation into Theology: The Rich Variety of Theology and Hermeneutics, Pretoria: J L van Schaik, 451-470.

Hoedendijk, J C 1964. De Kerk Binneste Buiten. Amsterdam: Ten Have.

Huber, W 1993. Toward an Ethics of Responsibility. Journal of Religion 73(4), October 1993, 573-591.

Kgatla, S T 1995. Dark valleys of death and shining stars in traditional African religions. Ned Geref Teologiese Tydskrif 36(1), 124-130.

Knitter, P 1985. No other name? A Critical Survey of Christian Attitudes toward the World Religions. New York: Maryknoll.

Kobia, S 2003. The Courage to Hope: The Roots for a new vision and the Calling of the Church in Africa. Geneva: WCC Publications.

Kotzé, E \& Kotzé D J 1997. Social construction as postmodern discourse: An epistemology for conversational therapeutic practice. Acta Theologica 17(1), 27-50. 
Kritzinger, J J 1987. Introducing Missiology in Pretorius, H L, Odendaal, A A, Robinson, P J \& Van der Merwe, G (eds), Reflecting on Mission in the African Context, Bloemfontein: Pro Christo Publications. 1-10.

Küng, H 1974. On being a Christian. Suffolk: Fount Paperbacks.

Lechte, J 1994. Fifty key Contemporary Thinkers: From structuralism to postmodernity. London: Routledge.

Lowe, W 1999. Prospects for a Postmodern Christian Theology: Apocalyptic Without Reserve. Modern Theology 15(1), January 1999, 17-24.

Magesa, L 1997. African Religion: The Moral Traditions of Abundant Life. New York: Orbis.

Maimela, S S 1985. Salvation in African Traditional Religions. Missionalia 13(2), August 1985, 63-77.

Mbiti, J S 1969. African religions and philosophy. London: Heinemann.

-, 1998. African Theology, in Maimela, S \& König, A (eds), Initiation into Theology: The Rich Variety of Theology and Hermeneutics, Pretoria: J L van Schaik, 141-158.

-, 2005. Interview on 20 January.

Meiring, P G J 1994. Mission: Who?, in Kritzinger, J J, Meiring, P G J \& Saayman, W A, On being Witnesses, Halfway House, Orion Publishers, 4072.

Milbank, J 1997. Postmodern Critical Augustinianism: A Short summa in Forty-two Responses to Unasked Questions in Ward, G (ed), The Postmodern God: A Theological Reader, Oxford: Blackwell Publishers, 265278.

Miller, J B 1989. The Emerging Postmodern World, in Burnham, F B (ed), Postmodern Theology: Christian Faith in a Pluralist World, San Francisco: Harper \& Row, 1-19.

Mitchem, S A 2002. “To Make the Wounded Whole”: Womanist Explorations of Reconciliation, in Ruether, Rosemary Radford (ed), Gender, Ethnicity, and Religion: Views from the Other Side, Minneapolis: Fortress Press, 247262.

Mutwa, V C 1998. Indaba, My Children. Edinburgh: Payback Press.

Ndungane, N 2003. A World With A Human Face: A voice from Africa. London: SPCK.

Ndwandwe, H C N 2000. Reading 1 John in a Zulu context: hermeneutical issues. Unpublished dissertation, University of Pretoria.

Niemandt, C J P 2007. Ontluikende Kerke - 'n nuwe missionêre beweging. Verbum et Ecclesia 28(2), 542-557.

Nolan, A 1988. God in South Africa: The challenge of the gospel. Cape Town: David Philip. 
Oduyoye, M A 1998. African Women's Hermeneutics, in Maimela, S \& König, A (eds), Initiation into Theology: The Rich Variety of Theology and Hermeneutics, Pretoria: J L van Schaik, 359-372.

Ruether, R R 2002. Preface, in Ruether, R R (ed), Gender, Ethnicity, and Religion: Views from the Other Side, Minneapolis: Fortress Press, ix-xv.

Schmidt, R 1988. Exploring Religion. Belmont: Wadsworth Publishing Company.

Smit, D J 2002. In diens van die tale Kanaäns? Oor sistematiese teologie vandag? Ned Geref Teologiese Tydskrif 43(1-2), 94-127.

Theron, P F 1996. African Traditional Cultures and the Church. Pretoria: IMER.

Thorpe, S A 1991. African Traditional Religions. Pretoria: University of South Africa.

Tutu, D M 1996. An African Prayer Book. Cape Town: Double Story.

-, 1999. No Future Without Forgiveness. London: Rider.

Ubruhe, J O 1996. Traditional Sacrifice: a Key to the Heart of the Christian Message. Journal for Theology in Southern Africa 95, 13-22.

Van Biema, David 2004. Why did Jesus die?, Time 163(15), April 12, 36-43.

Van de Beek, A 2004. Christology in the Netherlands. REC Focus 4(2), June 2004, 33-49.

Veldsman, D 1998. Theology: the $20^{\text {th }}$ century, in Maimela, S \& König, A (eds), Initiation into Theology: The Rich Variety of Theology and Hermeneutics, Pretoria: J L van Schaik, 49-80.

Vosloo, R 2004. Etiek as optiek? Oor die rol van beelde en verbeelding in die Christelike morele lewe. Ned Geref Teologiese Tydskrif 45(1-2), 137-150.

Wolfreys, J 1998. Deconstruction Derrida. London: Macmillan. 